\title{
THE INFLUENCE OF FIRM ECOLOGICAL RECRUITMENT ADVERTISEMENTS ON ORGANIZATIONAL ATTRACTIVENESS AND CAREER CHOICES: An Experimental Research*
}

\author{
Pracoyo Budi Jatmiko
}

\begin{abstract}
This present study investigates college students' interest to a green company and intention to work for the company. This study also investigates how much salary they are willing to receive to work for the company. The results of the study show construct validity evidence that being attracted to the organization and desire to pursue ajob in the organization are divergence constructs. Both constructs are influenced by different factors in magnitude. This study also finds that environmental information stated in the recruitment brochure can positively influence applicants' interest and intention to pursue a job in the company. Yet, applicants only react positively to an environment-friendly company that offers high pay level. They are more attracted to an environment-friendly company that offers high pay level. However, this relationship does not influence applicants' intention to pursue a job. Applicants' personal concern on the environment do not influence applicants' interest and intention to pursue a job in a green company. This suggests that a positive environmental information articulated in the recruitment brochure could positively affect potential recruits, even when applicants did not personally see herself or himself as being particularly pro-environment.
\end{abstract}

Keywords: homogeneity test; job pursuit intention; organizational attractiveness; personal environmental stance; social desirability

* This article is a part of my thesis in Magister Sains Gadjah Mada University in 2001. I am greatful to the University Research for Graduate Education (URGE) and the Collaborative Environmental Program for Indonesia (CEPI) that funded this research. The researcher also wants to give great gratitude to Dr. Hani Handoko, M.B.A. and Dr. Bambang Riyanto, M.B.A. for their guidances and comments on making this research. 


\section{Introduction}

It is argued that attracting top quality candidates is an important duty to be accomplished (Lado and Wilson 1994). In doing so, the inexpensive way to attract applicants can be done by using company recruitment ads. Onestudy found that positive information about a company, which was stated in the recruitment advertisements, would increaseapplicants' interest on the company (Gatewood et al. 1993). Based on that idea, this study investigates the applicants' interest and applicants' desire to pursue a job in an environmentfriendly company. This study also examines how much salary they are willing to receive to take a job in an environmentfriendly company. Thus, this study investigates themoderating effect of applicants' personal environmental concern to the applicants' job decision. Finally, this study examines the validity construct of being attracted to an organization and the desire to pursuea jobin an organization that is still on the academic debates (Aiman-Smith et al. 1999).

The idea to investigate applicants' interest and applicants' career choices in an environment-friendly company came from the increasing society's concern to natural environment preservation (Economist 1994). Individuals now are stressing the importance of environment. A recent US survey finds that individuals - by ratio six to one- have strong willingness to pay more for products that save the environment (Rosewicz 1990). In the US there was popular publication handbooks, such as The Green Consumer Supermarket Guide that informed the society about the environment friendly product, which could influence the buying behavior. It was also found that eight to ten Americans were environmentalists. People in the US were reporting that they tookenvironmental concerns into account in their daily activities (Bucholz 1991). Environmental preservation also becomes one of the vital programs on the agreement between IMF and Indonesia's government.

There are redundant evidences showing how people concern to the environmental protection policy. However, there are limited empirical studies that explore environmental issues in the recruitment stance. From briefliterature review, there are only four studies that explored environmental issues in this area (Strand etal. 1981; Bauer and Aiman-Smith 1996; Turban and Greening 1997; Aiman-Smith et al. 1999). Strand et al. (1981) find that company's environmental policy influenced applicants' jobdecision. Bauer and Aiman-Smith (1996) also find the same results. Those studies are supported by others' studies (Turban and Greening 1997; Aiman-Smith etal. 1999)

Since there are limited studies on environmental preservation in the recruitment stance, this encourages the researcher to investigate these issues. This study is in part a replication of the Bauer and AimanSmith's (1996) work with adding pay level manipulation. The reason of this (part) replication because Indonesia is a developing country (not to say a poor country) in which the publications and education of the importance of the environmental preservation are verylimited compare to the US. So that, it is argued that there are differences between US and Indonesian students in rating environment-friendly company. Besides, pay emerged as a consistently important attribute in a number of recruitment studies (Strand et al. 1981; Aiman-Smith et al. 1999). Therefore, using this variable in this study will give great benefit. Bauer and Aiman-Smith(1996) also stated that the limitation of their study was 
Jatmiko-The Influence of FirmEcological Recruitment Advertisements On...

on the exclusion of the paylevel manipulation. They wondered whether applicants' are willing to be paid in low pay level in an environment-friendly company. Thus, they call for future research to investigate this relationship. This study tries to grab the call.

The idea to examine the moderating effect of applicants' personal environmental concern to the applicants' job decision came from person-organization fit theory. The theory explains that an individual tends to find a job in a company with values that fit with his or her own values (Judge and Bretz 1992). It means individual who considers ecological preservation as his or her personal value will be attracted to an environment-friendly company. On the other hand, an individual who does not consider ecological preservation as his or her personal value will react neutral to an a green company. Similar relationship is happened for applicants' intention to pursue a job in an organization.

\section{The Influence of Firm Ecological Recruitment Advertisements on Organizational Attractiveness and Job Pursuit Intention}

A survey found that employees viewed a firm's environmental performance and whether it fitted their values profile frequentlyaffected their willingness to work on that firm (Dechant and Altman 1994). A 1991 McKinsey's study of 403 senior executives from around the world revealed that sixty-eight percent of them agreed that 'organizations with a poor environmental record would find it increasinglydifficult to retain high caliber staff' (McKinsey and Company 1991). This perspective was validated by Mike Joyce, Director of Environmental Affairs for Dexter Corporation, who indicated that "college graduates are look- ing for more just a paycheck, they are looking for companies with which they can identify morally and philosophically" (Russo andFouts 1997). Moreover, certain companies, such as IBM, General Motors, and Microsoft used environmental preservation messages on their recruitment advertisements to attract applicants (Turban andGreening 1997).

One study ranked four factors that influenced applicants' interest (Strand et al. 1981). The study found that individual development was the most important attribute to them, which then followed in order by pay, environmental responsibility, and fair employment. Another study found that environmental responsibility is the most important factors, which influenced applicants' interest(Aiman-Smith et al. 1999). Other attributes that followed were lay-off policy, pay, and promotional opportunity. More direct study found that ecological recruitment advertisement predicts applicants' interest (Bauer and AimanSmith 1996).

However, in assessing intention to pursue employment, student rated pay as the most important attributes followed by lay-off policy, promotional opportunity, and ecological rating (Aiman-Smith et al. 1999). Judge and Bretz (1992: 270) also indicated "job seekers" perceptions of organizational values might be influenced by “environmental protection policy." More direct study found that ecological recruitment advertisements predicts applicants' intention to pursue employment (Bauer and Aiman-Smith 1996). Since the awareness of Indonesians to the environmentfriendly firms is doubted, the ecological recruitment advertisements might not influence either applicants' interest or applicants' intention to pursue a job. This study is designed to test the student job decisions in a "green" company. 
Considering the surveys and research above, it is hypothesized that ecological recruitment messages will influence applicants' assessment on organizational attractiveness and job pursuit intention.

Hypothesis 1a: Applicants will be more likely to rate an environment-friendly company as moreattractive than acompany offers no ecological statement.

Hypothesis 1b: Applicants will be more likely to pursue employment opportunities with an environment-friendly companythan with a company offers no ecological statement.

\section{The Interaction Effect of Ecological Messages and Pay Level}

Aiman-Smith etal.(1999) find that pay is themost important variable to predict job pursuit intention followed bylay-off policy, promotional opportunity and ecological rating. Strand et al. (1981) also find similar results. They find that pay was an important variable which influence job decision followed by environmental responsibility.

On the other hand, Judge and Bretz (1992) find that organizational values, such as concern for others, achievement, honesty, and fairness are rated higher by applicants than pay in predicting job offers acceptance. Another study find that environmental preservation is the most important variable to influence applicants' interest followed by lay-off policy, salary and promotional opportunity(Aiman-Smith et al. 1999).
Considering environment and high pay as important variables in making job decision, there might be an interaction effect between ecological messages and high pay level. It is predicted that applicants will be more attracted to a company that concerns to the environmental preservation and offers high pay level.

Hypothesis 2a: Applicants will be more likelyattracted to an environment-friendly company that offers high pay level.

Hypothesis 2b: Applicants will be more likely to pursue ajob from an environment-friendly company that offers high paylevel.

\section{The Moderating Effect of Personal Environmental Stance}

Person-organization fit theory explained that person tends to find a job that aligned his or her own values with the organization. Empirically, Judge and Bretz (1992) find that applicant's acceptance on a job was highest when a match existed between subject's personal values and the value of the organization. The study also find that personal values' preferences, such as concerns for others, achievement, honesty, and fairness moderate the relationship between organizational work values with individual decision to accept a given job offer. It means that applicants who valued concern for others, achievement, honesty, and fairness as their important values are more likely to accept a job offered from an organization in which concern for others, achievement, honesty, and fairness are emphasized. More directly, Bauer and Aiman-Smith (1996) indicated 
Jatmiko-The Influence of FirmEcological Recruitment Advertisements On...

that individual ecological orientation will moderate the relationship between company ecological stance with perceived attractiveness of the company and job pursuit intentions.

Considering theory and empirical research above, an individual who valued environment as his or her personal values will react more positively to an environment-friendlycompany than individual who does not judge environment as his or her important personal value. Therefore, it is predicted that individual ecological orientation will moderate the relationship between company ecological rating and the assessment of perceived attractiveness. A similar relationship also influences job pursuit intention.

Hypothesis 3a. Individual ecological orientation will moderate the relationship between companyecologicalstance and the perceived attractiveness of the company.

Hypothesis $3 b$ : Individual ecological orientation will moderate the relationship between companyecologicalstance and the perceived intentions to pursue a job in the company.

\section{Method}

\section{Subjects}

A total of 348 undergraduate students from Gadjah Mada University and the University of Indonesia participated in this study. The subjects in these experiments at least have to reach five academic semesters on which they commonly start to apply for jobs. They are used in this study with three reasons. First, they are undergraduate students who will be in the labor market soon. Second, Yogyakarta and Jakarta are two cities that have different environmental policies and standards. Jakarta is much more polluted city compares to Yogyakarta; so environmental preservation policies in Jakarta are much tighter compared to Yogyakarta. Using those two different areas would also enhance the generalizability of the results. Third, Gadjah Mada University and the University of Indonesia are distinguished universities that usually produce high caliber graduates and I believe theywould be a recruitment target for many companies. The entire subjects have major on management and accounting. The subjects were divided into four groups: Experiment $1(\mathrm{n}=87)$, Experiment $2(\mathrm{n}=87)$, Experiment $3(n=87)$ and Experiment $4(n=87)$. In each group, the subjects received different manipulation brochures. The description of each of the groups is as follows:

Experiment $1=$ without environmental messages, offers lowpay level

Experiment $2=$ withenvironmentalmessages, offers lowpaylevel

Experiment $3=$ without environmental messages, offers high paylevel

Experiment $4=$ withenvironmentalmessages, offers high pay level.

Fifty-one percent of the subjects were male and the rest were female. Regardless theirs working status, fifty-four percent of the subjects have ever been working. The grade point average (GPA) of the respondents ranged from 2 to 3.8 with an average of 2.91. The average age of the subjects was 22.8 years.

\section{Experimental Design}

This study is an experimental design with $2 \times 2$ between-subjects factorial designs. There are two conditions of ecological 
messages (with and without ecological messages) and two pay levels (high and low). Therefore, there are four groups: experiment 1, 2, 3 and 4. In order to ensure result validity, participants are randomly chosen. The experiments were conducted during class time. Each participant received a packet containing written instructions, a recruitment brochure of a fictitious company, and post-manipulation questionnaire. All the recruitment brochures are similar to the ordinary recruitment brochures, which usually used in campus recruitment and looks exactly alike. The differences between experiment and control brochures are just on the environmental policy statements and pay level information. The experiment groups 2 and 3 read a brochure with four lines describing the environmental stance of the fictious company embedded in the middle of the brochure. These lines read:

MultiElectro is also dedicated to the protection of the environment. We are a leader in our field when it comes to environment conciousness. We value environmental-friendly programs from office recycling to innovation in the reduction and disposal wastes. In addition, we encourage and reward employees' involvement at all levels of environment responsibility.

The brochures also describe the pay level manipulations. Low pay level information is described in experiment brochure 2. High pay level information is described in experiment brochure 4. The pay level information is provided from a survey using samples from senior undergraduate students. Researcher asked students answering questions about "how much first salary are you going to ask if you work for a company' and a few demographic questions. The survey conducted during class time. Forty-nine senior students participated in this survey. Three students were excluded from the survey because they wanted to continue their study to master program and they mentioned their salary demand after they graduate from the master program. The pay levels are established using the average and standard deviations of salaries that students mentioned. The average monthly starting salary of fresh graduate was Rp1,842,391.00. A low salary was calculated as one standard deviation below the mean or as equal as $\mathrm{Rp} 1,000,000.00$. The high salary is measured as one standard deviation above the mean or as equal as Rp2,700,000.00. The researcher does not use medium pay level because the objective of this study is to see the contrast between the two pay levels.

The experimental brochures 1 and 3 did not mention environmental information. However, the brochures contained paylevel which is exactly the same with the treatment of brochure 2 and 4 . Low pay level information is described in experimental brochure 2. High pay level information is described in experimental brochure 4 . Participants were asked to read the brochures carefully. After reading the brochures, participants were asked to complete the questionnaires about the organizational attractiveness, job pursuit intention, and other questionnaires that used as control variables, such as grade point average (GPA), age, work experience and gender. After completed all the questionnaires, participants were asked to complete the second questionnaire about personal environmental stance. Then, the social desirability questionnaire is the last questionnaire that has to be completed. 
Jatmiko-The Influence of Firm Ecological Recruitment Advertisements On...

\section{Measures}

Environmental Condition. Subjects in the experimental condition read a brochure that contained company information in four line in the middle of the brochure. The brochure read by control group was identical to the experimental one, with the exception of having no environmental information about the company. The environmental condition was dummy coded. The experimental condition was coded " 1 " and the control condition was coded " 0 ".

Pay Condition. Subjects in the experimental condition read a brochure of a company that offers high pay. Subject in the control group were identical to the experimental one, with the exception of offers low pay level. The condition was dummycoded. The experimental condition was coded " 1 " and the control condition was coded " 0 '.

Organizational Attractiveness. Organizational attractiveness was measured by 5 items developed by Schwoerer and Rosen (1989). Participants responded to the attractiveness statements by rating the degree to which they agreed with each of the statements using 7-point Likert-like scale. The scale ranged from "1" strongly disagree to "7" strongly agree. A sample item includes: "I find this a very attractive company".

Job Pursuit Intention. Job pursuit intention was measured by 6 items developed by Bauer and Aiman-Smith (1996). Participants responded to statements by rating the degree to which they agreed with each of the statements using 7-point Likertlike scale. The scaleranged from "1" strongly disagree to "7" strongly agree. A sample item includes: "I would attempt to gain an interview with this company."

Control Variables. Previous studies reported the importance of working experi- ence $(\operatorname{coded} 0=$ no experience; $1=$ experience), gender $(\operatorname{coded} 0=$ female; $1=$ male $)$, grade point average (GPA) and age on the assessment of organizational attractiveness and job pursuit intention (Judge and Bretz 1992; Bauer and Aiman-Smith 1996; Aiman-Smith etal. 1999). Therefore, those variables are used as control variables.

Personal Environmental Stance. Personal environmental stance will be used to measure participant individual concern on environmental preservation. This questionnaire used 10 item developed by Bauer and Aiman-Smith (1996). Participants rated the degree to which they agreed with each statement using 7-point Likert-like scale that ranged from "1" strongly disagree to "7" strongly agree. A sampleitem includes: "I really care about the environment."

Social Desirability. Social desirabilityquestionnaire was used to know whether students lie or not in filling personal environmental stance. This questionnaire was very important to be used in this study because sometimes people lie in answering the question. They lie with the purpose to be judged as environmentalist. This questionnaire was measured by 19 items developed by Paulhaus (1988). A sample item includes: "I sometimes tell lie if I have to."

\section{Method and Procedure}

Before being manipulated all items in the questionnaire will be factors analyzed using principal component analysis with varimax rotation. Factors were determined using combination rules: factor loading above .40 and theoretically rationale. All constructs' reliability were tested using Cronbach Alpha. The Cronbach Alpha values should be greater than .7 .

After their validity and reliability were tested, the data were analyzed using multiple regression. This instrument was used to test hypothesis 1. Hypothesis 2 was 
Gadjah Mada InternationalJournalof Business, May 2004, Vol. 6,No.2

tested by using analysis of variance (ANOVA). Analysis of variance required that sample of four experiment groups have identical variance. In order to assure that this assumption hold, homogeneity test of variance was conducted. Afterward, hierarchical regression is used to test Hypotheses 3 .

\section{Results}

Table 1 contains a summary of validity test results of the four experimental conditions. The test revealed two factors. Items 1,3,4, 7, 8, 9 and 11 were categorized as the first factor. This factor was named as organizational attractiveness $(\mathrm{OA})$. Items

Table 1. Results of Factor Analysis with Varimax Rotation of The Entire Experimental Groups

\begin{tabular}{|c|c|c|c|}
\hline No. & Item & $\begin{array}{c}\text { Factor 1 } \\
\text { Organizational } \\
\text { Attractiveness }\end{array}$ & $\begin{array}{l}\text { Factor } 2 \\
\text { Job Pursuit } \\
\text { Intention }\end{array}$ \\
\hline 1. & I would accept a job offer from this company & .70 & .41 \\
\hline 2 & I would request more information about this & .11 & .84 \\
\hline 3 & This would be a good company to work for & .74 & .34 \\
\hline 4 & $\begin{array}{l}\text { I would attempt to gain an interview with } \\
\text { the company }\end{array}$ & .53 & .66 \\
\hline 5 & $\begin{array}{l}\text { I would want a company like this in } \\
\text { my community }\end{array}$ & .50 & .48 \\
\hline 6 & $\begin{array}{l}\text { I would try to persuade this company to visit } \\
\text { this campus to recruit or participate in } \\
\text { a career fair }\end{array}$ & .41 & .47 \\
\hline 7 & This would like to work for this company & .71 & .51 \\
\hline 8 & This company cares about its employees & .78 & .006 \\
\hline 9 & $\begin{array}{l}\text { I would recommend that my friend interview } \\
\text { with this company }\end{array}$ & .73 & .15 \\
\hline 10 & $\begin{array}{l}\text { I would interest in speaking to the representative } \\
\text { of this company if one were visiting on campus }\end{array}$ & .14 & .75 \\
\hline 11 & I find this a very attractive company & .66 & .48 \\
\hline
\end{tabular}

The cronbach alpha score was 0.9 .

Items number $3,4,5,7,8$, and 11 became one factor. It was named as organizational attractiveness. Items number 2, 4, 6 and 10 became one factor. It was named as job pursuit intention.

Items number 1 and 9 were excluded from the analysis because these items did not fit with the measured concept. 
Jatmiko-The Influence of FirmEcological Recruitment Advertisements On...

2, 4, 6 and 10 were categorized as the second factor. This factor was named as jobpursuit intention(JPI). Thereliability of each of the conditions was .90 (Cronbach alpha value). Theoretically, item 1 and 9 should be categorized as the second factor instead of the first factor In order to be consistent with the previous theory (Aiman-Smith et al. 1999), therefore item 1 and 9 were excluded from the analysis.

Hypothesis 1a states that applicants will be more likely to rate an environmentfriendly company as more attractive than a firm offers no ecological statement. Table 2 contains the test of the hypothesis. A multiple regression test showed that independent variable environmental condition positively influenced organizational attractiveness $(\mathrm{p}<.01)$. This result suggests that applicants tend to rate an environment- friendly company as a more attractive organization than a company without any environmental concern. Hypothesis $1 \mathrm{a}$ is supported.

Hypothesis $1 \mathrm{~b}$ states that applicants will be more likely to pursue employment opportunities with an environment-friendly company than with a firm offering no ecological statement. Table 2 contains the test of the hypothesis. A multiple regression showed that variable independent environmental condition modestly influenced job pursuit intention $(\mathrm{p}<.10)$. Although not strong in magnitude, this result suggests that applicants tend to pursue employment to an environment-friendly company than to a company that does not state their concerns to the environment. Hypothesis $1 \mathrm{~b}$ is supported.

Table 2. Regression Results

\begin{tabular}{lcc}
\hline \multirow{2}{*}{ Variable } & \multicolumn{2}{c}{ Dependent Variable } \\
\cline { 2 - 3 } Constant & $\begin{array}{c}\text { Organizational } \\
\text { Attractiveness }\end{array}$ & $\begin{array}{c}\text { Job Pursuit } \\
\text { Intention }\end{array}$ \\
\cline { 3 - 3 } Age & $4.57 * *$ & $5.39 * *$ \\
Gender & .04 & -.07 \\
GPA & $-.14 *$ & -.01 \\
Working Experience & .04 & $.094 \dagger$ \\
EnvironmentalCondition & .07 & .02 \\
Pay Condition & $.21 * *$ & $.10 \dagger$ \\
R-Square & $.11 \dagger$ & .005 \\
F-value & .07 & .022 \\
Levene Statistics & $4.47 * *$ & 1.53 \\
\hline
\end{tabular}

\section{$\mathrm{N}=348$}

Gender: $1=$ Male, $0=$ female;

Working Experience: 1= experienced, $0=$ unexperienced;

Environmental Condition: $1=$ with environmental messages, $0=$ without environmental messages; Pay Condition: 1= offers high pay level, $0=$ offers low pay level.

$\dagger \mathrm{p}<0.10$

$* \mathrm{p}<0.05$

$* * \mathrm{p}<0.01$ 
A multiple regression in Table 2 also indicated that pay group positively influence organizational attractiveness $(\mathrm{p}<.10)$. This suggests that applicants are more attracted to a company offers high pay level than a company offers low pay level. Table 2 also showed that pay group positively influenced job pursuit intention. This suggests that applicants more intend to pursue a job in a company which offers high pay than a company which offers low paylevel. A control variable gender significantly influenced organizational attractiveness (see Table 2). A control variable grade point average (GPA) significantly influenced job pursuit intention.

Test of homogeneity of variances showed that the Levene Statistic score was $.87(\mathrm{p}>.05)$ for all of the experiment group samples with the independent variables organizational attractiveness (see Table 2). This suggested that the variances of all experiment groups was identical. This resultaligned with the assumption of ANOVA test. So did with all samples of the independent variables job pursuit intension. The Levene Statistic score was 1.28 ( $\mathrm{p}>.05)$.

Hypothesis 2a states that applicants will be more likely attracted to an environment-friendly company that offers high pay level. An ANOVA showed that there was a significant mean difference between experimental group 4 and experimental group $1(\mathrm{p}<.001)$. Thus, there was a significant mean difference between experimental groups 4 and experimental groups 3 (p $<.001)$. The $F$-value also supported this results $(F$-value $=7.042 ; \mathrm{p}<.001)$. However, there is no significant mean difference between experimental group 4 and experimental group $2(\mathrm{p}=.193)$. This suggests that applicants will be more attracted to an environment-friendly company that offers high pay level. Hypothesis 2a is supported.

Figure 1. Scheme of the Interaction Effect between Environmental Messages and Pay Level Manipulation (Dependent Variable: Organizational Attractiveness)

\begin{tabular}{|c|c|c|}
\hline & $\begin{array}{c}\text { Without } \\
\text { Environmental } \\
\text { Messages }\end{array}$ & $\begin{array}{c}\text { With } \\
\text { Environmental } \\
\text { Messages }\end{array}$ \\
\hline $\begin{array}{l}\text { Low } \\
\text { Pay }\end{array}$ & $\begin{array}{l}\text { No Significant } \\
\text { Difference } \\
\text { (Experiment1) }\end{array}$ & $\begin{array}{l}\text { NoSignificant } \\
\text { Difference } \\
\text { (Experiment2) }\end{array}$ \\
\hline $\begin{array}{c}\text { High } \\
\text { Pay }\end{array}$ & $\begin{array}{l}\text { NoSignificant } \\
\text { Difference } \\
\text { (Experiment3) }\end{array}$ & $\begin{array}{c}\text { The Most Effective } \\
\text { Advertisements to Attract } \\
\text { Applicants } \\
\text { (Experiment4) }\end{array}$ \\
\hline
\end{tabular}


Jatmiko-The Influence of FirmEcological Recruitment Advertisements 0n...

Figure 1 shows the summaryof the ANOVA test results.

Hypothesis $2 \mathrm{~b}$ states that applicants will be more likely to pursue a job in an environment-friendly company that offers high paylevel than an environment-friendly company that offers low pay level. An ANOVA showed that there was no significant mean differenceamong 4 experimental conditions. Hypothesis $2 \mathrm{~b}$ is not supported.

Hypothesis 3a states that individual ecological orientation will moderate the relationship between company ecological stance with the perceived attractiveness of the company. This hypothesis was tested using hierarchical regression. The tests were conducted into three steps. A hierarchical regression showed that there were increments $R$-square from Model 1,2, and 3 (see Table 3 ). The increments were slightly high from .064 (Model 1) increased to .099 (Model 2) and finally to .137 (Model 3). However, there was serious multicolinearity between independent variable group and interaction variable pes $\mathrm{x}$ groups (correlation score $=.986$ ). Therefore, hypothesis $3 \mathrm{a}$ is not supported.

Table 3. Regression Results

\begin{tabular}{|c|c|c|c|c|c|c|}
\hline \multirow[b]{2}{*}{ Variable } & \multicolumn{3}{|c|}{$\begin{array}{c}\text { Dependent Variable: } \\
\text { Organizational Attractiveness }\end{array}$} & \multicolumn{3}{|c|}{$\begin{array}{l}\text { Dependent Variable: } \\
\text { Job Pursuit Intention }\end{array}$} \\
\hline & Model 1 & Model 2 & Model 3 & Model 4 & Model 5 & Model 6 \\
\hline Constant & $5.027 *$ & 3.505 ** & $4.632 * *$ & $5.409 * *$ & $3.496 *$ & 4.532 ** \\
\hline Age & .004 & $-5.731 \mathrm{E}-05$ & .013 & -.069 & -.074 & .022 \\
\hline Gender & $-.122 *$ & $-.117 *$ & $-.122 *$ & -.009 & -.002 & .009 \\
\hline GPA & .033 & .039 & .050 & $.094 \dagger$ & $.101 \dagger$ & .049 \\
\hline $\begin{array}{l}\text { Working } \\
\text { Experience }\end{array}$ & .747 & .024 & .005 & .018 & -.007 & -.003 \\
\hline Group & $218 * *$ & $253 * *$ & -1.211 & $.101 \dagger$ & $.145 * *$ & $-2.819 * *$ \\
\hline PES & & $.193^{* * k}$ & .028 & & $240 * *$ & .059 \\
\hline PESxGroup & & & $1.46 * *$ & & & $2.984 * *$ \\
\hline RSquare & .064 & .099 & .13 & .022 & .077 & .456 \\
\hline $\begin{array}{l}\text { RSquare } \\
\text { Change }\end{array}$ & & .035 & 0.031 & & .055 & 379 \\
\hline F-test & $4.68 * *$ & $629 * *$ & $731 * *$ & 153 & $4.76^{* *}$ & $4.76^{* * *}$ \\
\hline
\end{tabular}

$\mathrm{N}=348$

Gender: $1=$ Male, $0=$ female;

Working Experience: 1= experienced, 0= unexperienced;

Group: $1=$ with environmental messages, $0=$ without environmental messages.

$\dagger \mathrm{p}<0.10$

$* \mathrm{p}<0.05$

$* * \mathrm{p}<0.01$ 
Hypothesis $3 b$ states that individual ecological orientation will moderate the relationship between company ecological stance with the perceived intentions to pursue a job in the company. The hierarchical regression showed that there were increments $R$-square from model 4, 5 and model 6 (see Table 3). Again, the increments were slightlyhigh from.022 (Model 4) increased to .077 (Model 5) and finally to .456(Model 6). However, there was serious multicoliniarity between independent variable group and interaction variable pes $\mathrm{x}$ groups (correlation score= 976). Hypothesis $3 \mathrm{~b}$ is not supported.

There were worries that students responded in a social desirability manner. To address this issue, the social desirability instruments were regressed with the organizational attractiveness and job pursuit intention. The regression results showed that social desirability did not significantly predict organizational attractiveness nor did job pursuit intention. It means that participants did not respond in social desirability manner. They responded the questionnaires seriously.

\section{Discussion}

This study shows evidence that organizational attractiveness and job pursuit intentions are divergence constructs. This study supports Bauer and Aiman-Smith (1996) findings. This study also supported Aiman-Smith et al. (1999). On the other hand, this study contradicts with Rynes (1991) who thought that organizational attractiveness and job pursuit intention are not different constructs. The findings of the study add empirical evidence on the test validity. To confirm this finding, future recruitment research should investigate further the difference between organizational attractiveness and job pursuit inten- tions. Such research would lead to greater clarity and specification of these variables.

The present study find that environmental information stated in the recruitment brochure could positively influence applicants' interest and intention to pursue a job to the company. These findings support Bauer and Aiman-Smith findings (1996) and Aiman-Smith et al.s findings (1999). These findings indicate that there is no difference ecological awareness between American and Indonesian students. The possible reason to explain these phenomenon is that environmental awareness becomes a global awareness. It is not only become an important issue in the USA but also in Indonesia.

The findings of the study also find that applicants' interest to the company is influenced by pay level offered. Applicants tends to rate a company that offered high pay level as more attractive than a company offered low pay level. However, pay level does not significantly influence intention to pursue a job.

The present study finds that interaction effect between environmental preservation messages and high pay levels significantly influence organizational attractiveness. However, those do not have any effect on job pursuit intention. This suggests that combination between positive organizational values and job factors can create synergy affecting organizational attractiveness. These findings complement Bauer and Aiman-Smith (1996) who questioned how much applicants' salary demand to work in an environment-friendly company. Future research should address the interaction effect between other organization values and other job characteristics. For organizational images, researchers can study other dimensions of corporate social performance such as communityrelations, employee relations, product 
Jatmiko-The Influence of FirmEcological Recruitment Advertisements On...

quality, and treatment of women and minorities. For job factors, they can explore promotional opportunity, geographic location, type of work, and type of organization.

Applicants' personal concern on environment preservation does not moderate the relationship between company ecological stance and organizational attractiveness. This suggests that regardless applicants' personal concern on the environment, applicants tend to assess a proenvironment firm as an attractive organization. Applicants' personal concern on environment preservation does not moderate the relationship between company ecological stance and job pursuit intention. This suggests that regardless applicants' personal concern on the environment, applicants tend to pursue employment in proenvironment company.

The results of the study have practical implications for companies who recruit on campus. One implication is that organizations, which care to the environmental preservations, should state these practices in their recruitment advertisement in order to attract recruits. They should also publicize this practice to the community in order to get positive image from the society. Attracting high quality candidates was an initial step to create sustainable competitive advantages.

This study finds that a "green" company empirically can attract high quality candidates. So that, publicizing company policy on the environmental preservation can create sustainable competitive advantages. In other words, it can be said that good environmental responsibilitywill also create "goodbusiness". Small and medium enterprises that concern to the environmental preservation should use this recruitment strategy in attracting high potential candidates. Then, the organizations should focus on pay and other job characteristics when actually interviewing candidates. One particular, problem arises for big enterprises that pollute the environment. Even though theycan offer high pay level, applicants will not be interested to work for the company. In contrast, this will be an advantage for giant companies that pro-environment and have a good funding.

\section{Study Limitation}

One potential limitation is that this study does not assess real job seekers. However, it can be argued that this study is robust because subjects will be on the labor market soon and they also will become applicants. In addition, the regression results showed that social desirability did not significantlypredict organizational attractiveness nor did job pursuit intention. It means participants respond the questionnaires seriously.

Considering that the characteristic of this study is laboratory experiment, therefore this study lacks of the external validity (Sekaran 1984). On the other hand, this study is strong on the internal validity (Sekaran 1984). To asses the realism and the generalizability of this replication, a field study is needed (Sekaran 1984). 


\section{References}

Aiman-Smith, L., T. N. Bauer, and D. M. Cable. 1999. Are you attracted? Do you intend to pursue? A recruiting policy-capturing study. Unpublished Article.

Bauer, T.N., and L. Aiman-Smith. 1996. Green career choices: The influence of ecological stance on recruiting. Journal of Business and Psychology 10 (4) (Summer): 445-458.

Bucholz, R. A. 1991. Corporate responsibility and good society: From economics to ecology. In Green Career Choices: The Influence of Ecological Stance on Recruiting. Edited by Bauer, T. N., and L. Aiman-Smith (1996) in Journal of Business and Psychology 10(4)(Summer): 445-458.

Cable, D. M., and T. A. Judge. 1994. Pay preferences and job search decisions: A personorganization fit perspective. Personnel Psychology 47:317-348.

Chatman, J. A. 1989. Improving interactional organization research: A model of personorganization fit. Academy of Management Review 14:333-349.

Cohen, J. R., L. W. Pant, and D. J. Sharp. 1998. The effect of gender and academic discipline diversity on the ethical evaluations, ethical intentions and ethical orientation of potential public accounting recruits. Accounting Horizons 12 (3) (September): 250270.

Dechant, K., and B. Altman. 1994. Environmental leaderships: From compliance to competitive advantage. Academy of Management Executive 8 (3): 7-10.

Economist. 1994. Brand new day. Economist 19(June): 71-72.

Fergusen, T. 1993. Business world: The color of money is ever sochic. Wall Street Journal 15(March 23).

Gatewood, R.D., M. A. Gowan, and G. J. Lautenschlager. 1993. Corporateimage, recruitment image, and initial job choice decision. Academy of Management Journal 36 (2): 414427.

Gerhart, B., and G. T. Milkovich. 1990. Organizational differences in managerial compensation and financial performance. Academy of Management Journal 8: 883-691.

Judge, T. A., and R. D. Bretz. 1992. Effect of work values and job choice decisions. Journal of Applied Psychology 77 (3): 261-271.

Kinder, P.D., S. D. Lydenberg, and A. L. Domini. 1990. Social Screen to Ratiings. Cambrige, MA: Kinder, Lydenberg and Domini and Co.

Klassen, R. D., and McLaughlin. 1996. The impact of environmental management on firm performance. Management Science 42 (8): 1199-1214.

Lado, A. A., and M. C. Wilson. 1994. Human resource systems and sustained competitive advantage: A competency-based perspective. Academy of Management Review (19): 699-727.

McKinseyand Company. 1991. The Corporate Response to The Environmental Challenge: 
Jatmiko-The Influence of FirmEcological Recruitment Advertisements 0n...

Summary Report. Amsterdam: McKinsey. In Russo, M. V., and P. A. Fouts. 1997. A resource-based perspective on corporate environmental performance and profitability. Academy of Management Journal 40(3): 534-559.

Paulhaus, D. L. 1988. Assessing self-deception and impression on management in self report. In Green Career Choices: The Influence of Ecological Stance on Recruiting. Edited by Bauer, T. N., and L. Aiman-Smith (1996) in Journal of Business and Psychology 10(4)(Summer):445-458.

Rosewicz, B. 1990. Americans are willing to sacrifice to reduce pollution they say. Wall Street Journal(April 20). New York.

Russo, M. V., and P. A. Fouts. 1997. A resource-based perspective on corporate environmental performance and profitability. Academy of Management Journal 40 (3): 534559.

Rynes, S. L. 1991. Recruitment, job choice, and post-hire consequences: A call for new research direction. In Green Career Choices: The Influence of Ecological Stance on Recruiting. Edited by Bauer, T. N., and L. Aiman-Smith (1996) in Journal of Business and Psychology 10(4)(Summer): 445-458.

Schwoerer, C. E., and B. Rosen. 1989. Effects of employment-at-will policies and compensation policies on corporate image and job pursuit intentions. Journal of Applied Psychology 74: 653-656.

Sekaran, U. 1984. Research Methodfor Business: A Skill Building Approach ( $2^{\text {nd }}$ Ed. $)$. John Wiley and Son, Inc.

Strand, R., R. Levine, and D. Montgomery. 1981. Organizational entry preferences based upon social and personnel policies: An information integration perspective. In Green Career Choices: The Influence of Ecological Stance on Recruiting. Edited by Bauer, T. N., and L. Aiman-Smith (1996) in Journal of Business and Psychology 10 (4) (Summer): 445-458.

Turban, D. B., and T. L. Keon. 1993. Orgainzational attractiveness: An interactionist perspective. Journal of Applied Psychology 78 (2): 184-193.

Turban, D., and D. Greening. 1997. Corporate social performance and organizational attractiveness to prospective employees. Academy of Management Journal 40: 658672 . 